\title{
The Relationsip between Culture and Organizational Commitment among Chinese Primary School Teachers
}

\section{Arumugam Raman}

Universiti Utara Malaysia

arumugam@uum.edu.my

Lim Tse Ying

Universiti Utara Malaysia lim1706@yahoo.com

\section{Rozalina Khalid}

Universiti Utara Malaysia rozalina@uum.edu.my

Doi:10.5901/mjss.2015.v6n2s5p93

\begin{abstract}
The purpose of this study is to identify the relationship between school culture and organizational commitment. The study focused on twenty three Primary Chinese Schools (SJKC) in Kota Setar, Kedah, Malaysia. 200 teachers were randomly selected to be the respondents where they were asked to complete the School Culture Inventory (SCl) (Maslowski, 2001) questionnaire to test the school culture while Organizational Commitment (OC) (Meyer \& Allen, 1990) to examine teachers' commitment. Descriptive statistics of the SPSS (Statistical Package for the Social Sciences) version 19. 0 were used to analyze the data to determine the frequency, percentage, mean and standard deviation. Using Alpha Cronbachs, the reliability test of the instrument is 0.90 . To test the school culture and organizational commitment, statistical methods, descriptive and inferential statistics were used. Data collected was found to be not normal (K-S test) where Spearman correlation $p \leq 0.05$. Findings indicate that school culture is related to organizational commitment. Dimensions of human relations, open system, rational goal, internal process showed positive and significant relationships with organizational commitment, thus, proving that school culture is a predictor of organizational commitment.
\end{abstract}

Keywords: School Culture, Organizational Commitment, Chinese Primary School

\section{Introduction}

To materialise Mission 2020, the important aspect that needs to be addressed is the schools' organizational culture, teachers' commitment and school efficacy (Education Development Blueprint 2006-2010, 2007). Previous researches done showed the factor that impedes school success is the school organizational culture (Hopkins, 2005). Thus, in order to increase the quality of education we should focus on this factor.

Although similar curriculum is used throughout the schools in Malaysia, the school culture between the schools still differ. According to Marimuthu (1990), school culture consists of values, beliefs, knowledge and traditions, thinking styles and behaviours which are different from other social institutions. So, although schools are provided with the same infrastructure and work force the achievements of the schools still differ (Sharifah Md Nor, 2000; Huberman, 1992; Bolman \& Deal, 1991). This proves that school leadership plays an important role in determining school culture (Sergiovanni, 2000; Deal \& Peterson, 1999).

The performance of a school relates closely to teachers' high commitment for without it, the schools's target will be difficult to achieve. The effectiveness of teaching and learning depends on teachers' quality (Abdullah dan Ainon, 2005).

Teachers who are highly committed will ensure that every tasks delegated are completed successfully. Teachers' commitment is related to work performance and the ability to create and consolidate new ideas in their teaching, having influence on their students' achievement, and teachers' attitude towards the school (Tsui \& Cheng, 1999).

Studies about school culture in Malaysia and effective schools are still scarce (EPRD, 2004). Although studies 
conducted overseas are vast, majority are empirical qualitative studies and thus the data collection are from small schools (Colley, 1999; Kelley \& Bredeson, 1987). Other studies on school culture only focussed on comparison between secondary schools (Cavanagh \& Dellar, 1998; Pang, 1996). Therefore, this study aims to identify the school climate or culture at a primary chinese school (SJKC) in the district of Alor Setar and its relationship with teachers' commitment towards the school.

A study by Pang (1998) focussed on school culture in secondary schools in Hong Kong. Pang (1998) identified the school culture profile based on the composite score on four variable; bureaucratice relationship, culture relationship, authoritarian monitoring and laidback monitoring. However, Pang (1998) did not analyze the profiles to identify types of secondary school cultures. Thus, this study tends to explore the existence of types of secondary school cultures. The knowledge about school culture and values is vital. Schools can use this study to identify their own school cultures and display values that work towards their school success. If school cultures are identified, school administrators will be able to plan and implement appropriate actions to improve their schools.

Commitment also relates to the achievement of the organization's aims (Mintzberg, 1989). An effective should have committed teachers towards achieving the school's vision and mission. A study by Kushman (1992) showed that there is a strong relationship between commitment and school culture, collaboration and school climate. Nir (2002) stated that teachers' commitment is also related to the efficacy of the school, work performance, work satisfaction and students' achievement. Committed teachers are more motivated to work towards change and are responsible (Firestone \& Pennell, 1993) more sensitive, dedicated and diligent (Elliot \& Crosswell, 2003). Therefore, this study will focus on school culture and teachers' commitment of SJKC.

\subsection{Objectives}

The objectives of this study is to identify the school culture based on the dimensions such as human relation, open system, rational goals and internal process in SJKC in the district of Alor Setar in Kedah. This study also aims to examine the relationship between school culture and teachers' commitment.

i. $\quad$ To identify school culture dimensions at SJKC in the district of Alor Setar in Kedah.

ii. To identify the relationship between school culture and organizational commitment.

\section{Literature Review}

Fullan dan Hargreaves (1996) defines culture as beliefs, assumptions, and hope in terms of school operations. School culture is also defined as school beliefs and values that are shared together or agreed upon as true and accurate Hobby (2004). School culture aspects can be identified through similar content and strength (Maloswki, 1993). Content refers to basic assumption meaning, norms, and values shared together by the school community.

According to Pang (2006), the strength of a culture is a combination of a clear definition of values and the level of values and norms practices. The strength of a culture relates to the social control that suits the school's values and norms. A weak school culture generates teachers who only follow the set guidelines and do not act innovatively. A strong school culture will influence various values, norms, beliefs, symbols, traditions and language which will color the students' future. The school community has to be exposed to and practice good and effective moral values in line with the National Philosophy of Education (NPE) (Asmawati Suhid, 2005). School culture has to be identified and understood so as to increase school's performance and achieve the NPE objectives (PIPP 2006-2010, 2007).

$\mathrm{Ng}$ (2006) who conducted a school culture study in a normal primary school (SK) and SJK in Malaysia found that SK schools display hierarchy culture compared to SJK. The findings showed that younger teachers in SK respect their seniors, are humble and respectful; and maintain the good name of their schools. On the other hand, in SJK the teachers were more individualistic, selfish and outspoken although they know their words may hurt others and cause conflict.

Deal and Kennedy (1982) and Peters and Waterman (1982) suggested that the culture of an organization gives a great impact on the organization especially in terms of performance and commitment. Teachers' commitment is identified as one most critical factors to determine future performance of education and schools (Huberman, 1993). Teachers' commitment is related to work performance and the ability to create and consolidate new ideas in their teaching, having influence on their students' achievement, and teachers' attitude towards the school (Tsui \& Cheng, 1999). To maintain the energy and the working spirit, teachers should uphold their personal commitment towards work (Day, 2004).

There is positive relationship between organizational culture and organizational commitment among the Chinese community in Taiwan according to a study by Chow et al (2001). The dimensions such as innovation, aggression, respectful, and stability showed a strong relationship with commitment and work satisfaction. Team work showed average 
relationship. A study by Ritche (2000) showed that organizational culture has an influence and effect on the performance of an individual and organization.

There is positive relationship between secondary school teachers' commitment with school culture according to Jones (1998). 11 schools in New Jersey were tested by Jones (1998) to examine the relationship between commitment and school culture by involving the school administrators and teachers as respondents. The result showed that the relationship between variables such as loyalty, work environment, happiness, and information sharing among colleagues have positive relationship with commitment.

Three factors that influence teachers' commitment in schools are personal, school and system (Elliot dan Crosswell, 2001). Personal factor refers to personal daily life. Professional factor denotes to the importance of involvement and responsibility towards the profession. School factor relates to positive relationship with colleagues and the feeling of ownership while system factor refers to control, support, and teachers' influence towards the reform processes done. Lack of support from colleagues, students'parents and school administrators may influence teachers' commitment. It is difficult to be in schools that do not support change and development (Elliot \& Crosswell, 2001).

Lee et. al. (2010) suggested the orientation of school aims as an important factor that affects teachers' commitment. The relationship between the teachers, especially a collaborative relationship is one important factor suggested by several researchers in their studies on school culture and teachers' commitment ( Paine dan Ma, 1993 ).

The result findings of the study done by Wang et. al. (2007) showed that school culture affects teachers' commitment towards the school. Therefore, if a school increases the strength of its school culture, teachers will increase their loyalty. The literature review showed that the role of school culture is closely related to teachers commitment. The variables that relates to school culture have significant relationship on teachers' commitment towards school. The researcher aims to identify the relationship between school culture and teachers' commitment towards school.

There are five null hypotheses that will be studied here.

Ho1: There is no significant relationship between school culture and teachers' commitment.

Ho2: There is no significant relationship between human relations dimension and teachers' commitment.

Ho3: There is no significant relationship between open system dimension and teachers' commitment.

Ho4: There is no significant relationship between rational goal dimension and teachers' commitment.

Ho5: There is no significant relationship between internal process dimension and teachers' commitment.

\section{Method}

Since this study involved a huge number of respondents and there were differences between schools, a quantitative approach was suitable to be employed Pang (2006). Stratified random sampling was appropriate for mixed populations because this method could reduce the sample error, decrease variants, and give correct assumptions (Gorard, 2001), a less sample count and nearly represent a perfect population (Johnson \& Christensen, 2004). Size Determinant Table for educational research activities built by Krejcie and Morgan (1970) was used to determine the research sample and 228 teachers chosen from among several SJKC in the district of Kota Setar through simple random sampling were used as research sample.

To identify the school culture dimensions which focus on organizational efficacy values, questionnaire constructed by Krejcie dan Morgan (1970) was employed whereas to examine teachers' commitment Organizational Commitment (OC) (Meyer \& Allen, 1990) questionnaire was used. Section A consisted of teachers' personal information such as gender, marital status, age, ethnic group, years of teaching experience, years of teaching in the school and level of education. Section B involved 4 school culture dimensions which contained 10 to 11 items for each dimension (human relationship (1-11), open system (12-21), rational aims (22-31), internal process (32-42) and five options were given; Never (N), Very Seldom (VS), Seldom (S), Often (O), Very Often (VO). Section C dealt with teachers' commitment which involved 24 items based on Organizational Commitment (Meyer \& Allen, 1990) questionnaire. 5 Likert scale was given; 1= Disagree (D), 2= Slightly Disagree (SD), 3= Slightly Agree (SIA), 4= Strongly Agree (StA) and 5= Very Strongly Agree (VSA).

The pilot study was conducted at an SJKC in the district of Kubang Pasu to test the validity of the instrument. 45 teachers completed the questionnnaire and data analysis showed Alpha Cronbach Coefficient Value $(\alpha)=0.95$ which meant the instrument was suitable to be used in the real study.

\subsection{Data Collection}

After attaining the approval to conduct the study from EPRD and from the Education Department in Kedah, the 
researcher distributed the research instruments to the selected schools together with the documents listed below:

1. Letter to the Principal/Headmaster

2. Letter to the Teachers

3. A copy of approval letter to conduct the research

The respondents were given seven days to complete the questionnaire. Data collected was analysed by using SPSS (Statistical Package for the Social Sciences) version 19. 0. To describe sample characteristics and school culture dimensions, frequency, average, standard deviation, and percentage were used. Anomaly test were also conducted. Spearman Correlation test were used to identify the relationship between school culture and tecahers' commitment.

\section{Results}

\subsection{Demographic Information}

Research sample needed was 228 SJKC teachers in the district of Kota Setar. Although 240 sets of research instruments were distributed, only 210 were returned with the return rate of $87.5 \%$. But only 201 questionnaires could be analysed. Descriptive analysis was used to explain the respondents' information in terms of gender and marital status. Based on Table 1, there were 18 male teachers (9. 0\%) and 183 female teachers (91. 0\%) involved.

Table 1. Respondents' distribution based on gender

\begin{tabular}{ccc}
\hline Gender & Number of respondents & Percentage (\%) \\
\hline Male & 18 & 9.0 \\
Female & 183 & 91.0 \\
\hline Total & 201 & 100.00 \\
\hline
\end{tabular}

Table 2 shows the mean result of the overall culture which is 4 . 31 . Human relationship has the highest mean value which is 4. 49. The mean for other dimensions are high; with human relationship (4. 49) the highest, open system (4. 23), rational aims (4. 07), internal process (4. 43).

Table 2. Mean and Standard Deviation for school culture

\begin{tabular}{ccc}
\hline School Culture Dimensions & Mean & SD \\
\hline Human Relationship & 4.49 & 0.60 \\
Open System & 4.23 & 0.37 \\
Rational Aims & 4.07 & 0.45 \\
Internal Process & 4.43 & 0.75 \\
\hline Overall & 4.31 & 0.53 \\
\hline
\end{tabular}

To determine that the data collected is normal, anomaly test was conducted. Table 3 below shows the test result.

Table 3. Anomaly Test for school culture and teachers' commitment

\begin{tabular}{ccc}
\hline & Kolmogorov-Smirnova & Shapiro-Wilk \\
\hline Culture & .000 & .000 \\
Commitment & .000 & .000 \\
\hline
\end{tabular}

Shapiro - Wilk (W) test was . $702(p<.05)$ for school culture whereas for teachers' commitment Shapiro - Wilk (W) Test was ) . $647(p<.05)$. From the results, it showed that anomaly was not observed and so Spearman Test was used to test the relationship between school culture and teachers' commitment. 


\subsection{Hypothesis tesing}

$\mathrm{H}_{0} 1$ : There is no significant relationship between school culture and teachers' commitment.

Based on Table 4, the correlation analysis using Spearman test finding showed positive significant relationship between school culture and teachers' commitment $(r=.501, p<.05)$. This result rejected Ho1. The analysis finding showed that a high practice of scjool culture will result in high level of teachers' commitment. The correlation value between school culture and teachers' commitment was averagely high.

Table 4 Spearman Correlation between school culture variables and teachers' commitment variables

\begin{tabular}{ccc}
\hline \multirow{2}{*}{ Variables } & \multicolumn{2}{c}{ Teachers' Commitment } \\
\cline { 2 - 3 } & Correlation Value $(r)$ & Significant \\
\hline School Culture & $.501^{* \star}$ & .000 \\
\hline
\end{tabular}

\begin{tabular}{clccc}
\hline Hypotheses Hypotheses Statements & Method of Testing & Correlation Value & Test Findings \\
\hline $\mathrm{H}_{02}$ & $\begin{array}{l}\text { There is no significant relationship between human } \\
\text { relationship dimension and teachers' commitment at SJKC. }\end{array}$ & $\begin{array}{l}\text { Spearman } \\
\text { correlation }\end{array}$ & .998 & Rejected \\
\hline $\mathrm{H}_{04}$ & $\begin{array}{l}\text { There is no significant relationship between open system } \\
\text { dimension and teachers' commitment at SJKC. }\end{array}$ & $\begin{array}{l}\text { Spearman } \\
\text { correlation }\end{array}$ & .500 & Rejected \\
\hline $\mathrm{H}_{05}$ & $\begin{array}{l}\text { There is no significant relationship between rational aims } \\
\text { dimension and teachers' commitment at SJKC. }\end{array}$ & $\begin{array}{l}\text { Spearman } \\
\text { correlation }\end{array}$ & .502 & Rejected \\
\hline $\mathrm{H}_{06}$ & $\begin{array}{l}\text { There is no significant relationship between internal process } \\
\text { dimension and teachers' commitment at SJKC. }\end{array}$ & $\begin{array}{l}\text { Spearman } \\
\text { correlation }\end{array}$ & .502 & Rejected \\
\hline
\end{tabular}

Note: $p \leq 0.05$

Correlation analysis result using Spearman test in Table 5 showed positive significant relationship between human relationship dimension and teachers' commitment $(r=.998, p<.05)$ statistically. This result failed to accept Ho2. The high positive relationship showed that a high level of human relationship was able to increase the level of teachers' commitment and vice versa.

The relationship between open system dimension and teachers' commitment was also positive and significnt $(r=$. $500, p<.05)$ which also rejected Ho3. The result showed that high level of open system practice resulted in high level of teachers' commitment and vice versa. Similarly with $\mathrm{Ho4}$, there was positive significant relationship between rational aims and teachers' commitment $(r=.502, p>$. 05) which failed to accept Ho4. With this, there was an averagely high relationship between both variables. The positive significant relationship showed that high rational aims brought about high teachers' commitment. Finally, the result for $\mathrm{Ho5}$ was also significantly positive $(r=.52, p<$. 05) which showed an averagely high positive relationship between internal process dimension and teachers' commitment. This result failed to accept Ho5. The positive significant relationship showed that an effective internal process resulted in high teachers' commitment and vice versa. Overall, human relationship dimension showed a high correlation value $r=.998$ compared to other dimensions which gained $r$ value, $r=.50$.

\section{Discussion}

This study was conducted to identify the relationship between school culture and teachers' commitment at SJKC in Kota Setar district. This section will discuss the research questions and the findings. There are four school culture dimensions namely human relationship, open system, rational aims and internal process in this study. Overall, the mean score for all the four dimensions were high which exceeded 4 in the 5 Likert scale. The result finding showed that human relationship dimension is the dominant culture in SJKC with the mean value of 4. 49.

This finding is similar to the study by Maslowski (2001) in Holland. According to Maslowski (2001), schools in Holland showed a higher score in the human relationship dimension compared to the other dimensions. In addition, the result found is also in parallel with the result by (2003) in a university in the state of Ohio. According to Berrio (2003), the university culture focused on flexibility, human consideration, and sensitivity towards customers.

A journal written by Johnson (2002) also claimed that a small size school can brings about a better school culture. This is due to the fact that teachers are more focused on their students because of the small number of students and they have good relationship with the students' parents. According to Gruenert (2005), schools with high human relationship will produce a high number of successful students. 
The findings of this study are similar to the study done by Peterson and Deal (1999) who claimed that schools with high culture practice such as having the same goals and display good relationship with the surrounding community will increase teachers' commitment in schools. Peterson (2002) stated that schools with low culture practice will decrease the level of teachers' commitment to increase school achievement. The characteristics of low culture practice such as unclear vision and mission, no cooperation and unfriendly attitude with the surrounding community will decrease teachers' commitment.

Nevertheless, the finding of this study differs from the study findings by $\mathrm{Ng}$ (2006) which showed that the culture in SJKC did not emphasize on human relationship and internal process, instead, more focus is given to rational aims and open system. $\mathrm{Ng}(2006)$ said that teachers in SJKC are more individualistic in achieving the aims. They are more outspoken although their words might hurt other peoples' feelings and result in conflict. According to $\mathrm{Ng}$ (2006), teachers in SJKC are more responsible in undertaking their tasks because by doing so, they will be acknowledged.

Similarly, in a study done by Barth (2002), it was found that the dominant dimension is rational aims. His result finding is similar to the result by Yaakob (2007) who concluded that the dominant dimension in primary schools in Kedah is rational aims such as efficacy values, chasing aims and the success of aims orientation. The finding of this study proved that school culture has positive significant relationship with teachers' commitment at SJKC in Kota Setar district. From this result, research questions have been addressed and explained elaborately.

In materializing Vision 2020, the human capital needed originate from schools. School functions as the main education institution which is responsible to disseminate quality education to the children of our nation. Thus, teachers, as the main player in schools, should increase the quality of our education.

The government has realized that committed teachers will help in materializing the nation mission by practicing good school culture. Thus, school culture has been included in the Malaysian Education Blueprint (2013 - 2025).

The finding of this study has mentioned that human relationship dimension is the dominant school culture. So, school sustenance program, parents' financial resources and EDRP have encouraged the involvement of the PTA and parents in the program organized by the schools. Parents' support and involvement is important towards the success of the school programs and the increase of teachers' commitment.

In conclusion, the government especially the Ministry of Education should give emphasis on school culture which has impact on teachers' commitment. Teachers' commitment will increase if they work in a good school culture.

Teaching and learning will become more effective. School excellence will be achieved. The mission and vision of the Ministry of Education will materialize. Thus, education in Malaysia can be at par with other countries in the world.

\section{References}

Abdullah H. \& Ainon M. (2005). Kemahiran interpersonal untuk guru. Kuala Lumpur: PTS Publications \& Distributor Sdn. Bhd-

Aelterman, A. , Engels, N. , Van Petegem, K. , \& Verhaeghe, J. P. (2007). The well-being of teachers in Flanders: The importance of a supportive school culture. Educational Studies, 3 (33), 285-298

Akta Pendidikan 1961. (1984). Kuala Lumpur: International Law Book Service.

Anderman, Eric M. ; And Others. (1991) Teacher comitment and job satisfaction: The role of school culture and principal leadership. Retrieved from http: //files. eric. ed. gov/fulltext/ED375497. pdf

Asmawati, S. (2005). Pengajaran adab \& akhlak Islam dalam membangunkan modal. Jurnal Pengajian Umum (8), 167-177.

Barth, R. S. (2002). The culture builder. Educational Leadership, 59 (8), 6-11.

Berrio, A. A. (2003). An organizational culture assessment using the competing values framework: A profile of Ohio State University Extension. Journal of Extension, 41 (2), 1-12.

Bolman, L. G. , \& Deal, T. E. (1991). Reframing organizations. San Francisco: Jossey-Bass.

Cavanagh, R. F. , \& Dellar, G. B. (1998). The development maintenance and transformation of school culture. Retrieved from http: //files. eric. ed. gov/fulltext/ED418962. pdf

Cheng, Y. C. (1993). Profiles of organazational culture and effective school. School Effectiveness and School Improvement, 4 (2), 85 110.

Chow, M. , Carol, D. , Ruben, L. , \& Laurie, O. (2001). School reform organizing in the San Francisco Bay area and Los Angeles, California. Oakland, CA: California Tomorrow.

Colley, K. M. (1999). Coming to know a school culture. Retrieved from http: //scholar. lib. vt. edu/theses/available/etd-082599222148/unrestricted/KColley. pdf

Cunningham, W. , \& Gresso, D. (1993). Cultural leadership: The culture of excellence in education. Needham Heights, MA: Allyn and Bacon.

Day, C. (2004). A passion for teaching. London: Routledge Falmer.

Deal, T. E. , \& Kennedy, A. A. (1982). Corporate cultures: The rites and ritual of corporate life. Reading, MA: Addison-Wesley,.

Deal, T. E. , \& Peterson, K. D. (1990). The principal's role in shaping school culture. Retrieved from http: //files. eric. ed. gov/fulltext/ED3 
25914. pdf

Deal, T. E. , \& Peterson, K. D. (1999). Shaping school culture: The heart of leadership. San Francisco: Jossey-Bass.

Elliott, B. , \& Crosswell, L. (2003). Teacher commitment and engagement: The dimension of ideology and practice assocaited with teacherr commitment and engagement within an Australian perspective. Retrieved from http: //eprints. qut. edu. au/968/1/cro04237. pdf

Finnan, C. (2000). Implementing school reform models: Why is it so hard for some schools and easy for others? Retrieved from http: //files. eric. ed. gov/fulltext/ED446356. pdf

Firestone, W. A. \& Pennell, J. R. (1993). Teacher commitment, working conditions, and differential incentive policies. Review of Educational Research, 63 (4), 489-525.

Fullan, M. , \& Hargreaves, A. (1996). What worth fighting for in your schools? Retrieved from http: //files. eric. ed. gov/fulltext/ED342128. pdf

Gorard, S. (2001). Quantitative methods in educational research: The role of numbers made easy. London: Continuum.

Gordon, S. P. (2004). Profesional development for school improvement: Empowering learning communities. Boston: Pearson.

Gruenert, S. (2005). Correlations of collaborative school culture with student achievement. NASSP Bulletin, 89 (45), 1-9.

Hansen, G. and Wernerfelt, B. (1989). Determinants of firm performance: The relative impact of economic and organizational factors. Strategic Management Journal, 10 (3), 399-411.

Hinkle, D. E. ,Wiersma, W. , \& Jurs, S. G. (2003). Applied statistics for the behavioral sciences. Boston, Mass: Houghton Mifflin.

Hobby, R. (2004). A culture for learning: A investigation into the values and beliefs associated with effective schools. The Hay Group Management Ltd.

Hollins, E. (1996). Culture in school learning: Revealing the deep meaning. New Jersey: Lawrence Erlbaum Associates.

Hopkins, D. (2001). School improvement for real. London: Falmer Press.

Hopkins, G. (2005). Skilled leadership the key to improving test scores, study says. Education World Inc. Retrieved from http: // www. educationworld. com/a_admin/admin/admin188. shtml

Hoy, W. K. , \& Miskel, C. G. (2008). Educational administration: Theory, research, and practice (8th ed). New York, NY: McGraw-Hill.

Huberman, M. (1992). Successful school improvement. Buckingham: Open Univesity Press.

Huberman, M. (1993). The lives of teachers (J. Neufeld, Trans. ). London: Cassell Villiers House.

Issac, A. F. (1991). High- and low-burnout schools: School culture aspects of teacher burnout. The Journal of Educational Research, 84 (6), 325-333.

Johnson, R. B. , \& Christensen, L. B. (2004). Educational research: Quantitative, qualitative, and mixed approaches. Boston, MA: Allyn and Bacon.

Johnson, J. (2002). Do communities want smaller schools? Educational Leadership, 59 (5), 42-46.

Jones, A. H. (1998). Ten points of debate in teacher education. Teacher Educational Quaterly, 25 (4), 23-34.

Juhum, Muhammad. (2013). Hubungan budaya kerja, sikap terhadap kepemimpinan kepala sekolah, dan kepuasan kerja dengan komitmen organisasi guru smp swasta di Kecamatan Beringin Kabupaten Deli Serdang. Retrieved from http: //digilib. unimed. ac. id/hubungan-budaya-kerja-sikap-terhadapkepemimpinan-kepala-sekolah-dan-kepuasan-kerja-dengan-komitmen-organisasi-gurusmp-swasta-di-kecamatan-beringin-kabupaten-deli-serdang-29358. html

Kelly, B. E. , \& Bredeson, P. V. (1991). Measures of meaning in a public and in a parochial school: Principals as symbol managers. Journal of Educational Administration, 29 (3), 6-22.

Krejcie, R. V. dan Morgan, D. W. (1970). Determining sample size for research education and psychological measurement. Education and Psychological Measurement, 3, 607-610.

Kushman, J. W. (1992). The organizational dynamics of teacher workplace commitment: A study of urban elementary and middle schools. Educational Administration Quarterly, 28, 5-42.

Lee, O. F. , Tan, J. A. , \& Javalgi, R. (2010). Goal orientation and organizational commitment: Individual difference predictors of job performance. International Journal of Organizational Analysis, 18 (1), 129-150.

Macneil, A. , \& Maclin, V. (2005). Building a learning community democratic values. Retrieved from http: //cnx. org/contents/43c57343-bc b7-4066-8ac8-8f77d07c8884@2/Building_a_Learning_Community:

Manual Kajian Tindakan EPRD. (2004). Putrajaya: Kementerian Pendidikan Malaysia.

Maslowski, R. (1993). A systematic approach of organizational culture. Unpublished master's thesis, University of Twente, Netherlands.

Maslowski, R. (2001). School culture and school performance: An explorative study into the organizational culture of secondary schools and their effects. Retrieved from http: //doc. utwente. nl/36122/1/t0000012. pdf

Maehr, M. L. , \& Fyans, L. J. (1989). School culture, motivation, and achievement. Greenwich, CT: JAI Press.

Meyer, J. P. , \& Allen, N. J. (1990). The measurement and antecedents of affective, continuance and normative commitment to the organization. Journal of Occupational Psychology, 63 (1), 1-18.

Marimuthu, T. (1990). Pengenalan sosilogi Pendidikan. Kuala Lumpur: Fajar Bakti.

Mintzberg, H. (1989). Mintzberg on management. New York: Free Press.

Najeemah M. Y (2012). School climate and teachers ' commitment: A case study of Malaysia. International Journal of Economics Business and Management Studies, 1 (2), 65-75.

Nelson, D. L. , \& Quick, J. B. (2002). Understanding organizational behavior: A multimedia approach. Cincinnati: South-Western.

$\mathrm{Ng}, \mathrm{Y} . \mathrm{M}$. (2006). Principal leadership styles and management behaviour in two ethnic-cultural settings in Malaysia: A comparative case study. Tesis Doktor Falsafah. Universiti Sains Malaysia, Minden. 
Nir, A. E. (2002). School-base management and its effect on teacher commitment. International Journal of Leadership in Education, 5 (4), 323-341.

Ouchi, W. G. (1981). Theory Z: How American business can meet the Japanese challenge. Reading, Mass: Addison-Wesley Publishing Company.

Paine, L. , \& Ma, L. P. (1993). Teachers working together: a dialogue on organizational and cultural perspectives of Chinese teachers. International Journal of Educational Research, 19 (8), 675-697.

Pang, N. S. K. (2006). The organizationala values of Gimnaziala in Sovenia. Education Management Administration \& Leadership, 34 (3), 319-343

Pelan Induk Pembangunan Pendidikan 2006-2010. (2006). Retrieved from http: //www. smksgpusu. net/bahan/2007_plan_induk_1_5. pdf

Pelan Pembangunan Pendidikan 2013-2025. (2012). Retrieved from http: //www. moe. gov. my/userfiles/file/PPP/Preliminary-BlueprintBM. pdf

Peter, L. , \& John C. (2004). The effect of organisational culture and leadership style on job satisfaction and organisational commitment. Journal of Management Development, 23 (4), 321-338.

Peters, T. , \& Waterman, R. (1982), In search of excellence. London: Harper and Row.

Peterson, K. D. (2002). Positifve or negative? Journal of Staff Development, 23 (3), 10-15.

Prosser, J. (1999). The evolution of school culture research. In J. Prosser (Ed. ), School culture, 1-14. London: Paul Chapman.

Reza, S. , Jafar, R. S. , Mohammad, N. , Hasan, A. , \& Shahrookh, K. (2013). The relation of organizational climate and job motivation with organizational commitment of new employed teachers of physical education of educations and training administration in Kermanshah Province. Advances in Environmental Biology, 7 (13), 4084-4088

Robbins, S. P. , \& Coulter, M. (2003). Management (7th ed. ). New Jersey: Prentice Hall.

Sergiovanni, T. J. (2000). The lifeworld of leadership. San Francisco, CA: Jossey-Bass

Sharifah, M. N. (2000). Keberkesanan sekolah satu perspektif sosiologi. Kuala Lumpur: Universiti Putra Malaysia.

Schein, E. H. (1990). Organizational culture. American Psychologist, 4 (2), 109-119.

Schein, E. H. (2004). Organizational culture and leadership. San Francisco: Jossey-Bass.

Shore, L. M. , \& Wayne, S. J. (1993). Commitment and employee behavior: Comparison of affective commitment and continuance commitment with perceived organizational support. Journal of Applied Psychology, 28, 774-780.

Tsui, K. T. , \& Cheng, Y. C. (1999). School organisational health and teacher commitment: a contigency study with multi-level analysis. Educational Research and Evaluation, 5 (3), 249-268.

VanderStoep, S. , Anderman, E. M. , \& Midgley, C. (1994). The relationship among principal "venturesomeness" a stress on excellence and the personal engagement of teachers and students. School Effectiveness and School Improvement: An International Journal of Research, Policy and Practice, 5 (3), 254-271.

Wan Mohd. Zahid. (1993). Wawasan pendidikan, agenda pengisian. Kuala Lumpur: Nurin Enterprise.

Wang, H. K. C. , \& Hwang, F. C. (2007). Study on organizational culture, organizational commitment and attitude toward organizational reform—comprehensive high schools as example. The Journal of Human Resource and Adult Learning, 3 (2), 189-198.

Yaakob, D. (2007). Budaya sekolah rendah: hubungannya dengan kepemimpinan, komitmen organisasi dan pencapaian akademik. Tesis Doktor Falsafah. Universiti Sains Malaysia, Minden.

Yukl, G. A. (2002). Leadership in organizations (5th ed. ). Englewood Cliffs, NJ: Prentice Hall.

Zhu, C. , Devos, G. , \& Fei, L. Y. (2011). Teacher perceptions of school culture and their organizational commitment and well-being in a Chinese school. Asia Pacific Education Review, 12, 319-328. 